\title{
PRINCIPLES OF INTERNATIONAL LAW IN CONJUNCTION TO THE RECOGNITION, RESTITUTION AND COMPENSATION OF PROPERTY IN DIFFERENT STATES
}

\author{
Hemion Braho ${ }^{1}$ and Jonlinda Hada ${ }^{2}$ \\ ${ }^{1}$ PhD, Private Law Lecturer, ALBANIA, hemion.braho@uet.edu.al \\ 2 PhD Candidate, Private Law Lecturer, ALBANIA, jonahada@gmail.com
}

\begin{abstract}
Historically, property has been the foundation of the existence of human society and of states at all times. The "Rule of Law" in every democratic state guarantees and protects property. In a chronological period of time, how has the Albanian legal systems guaranteed private property? After the change of dictatorial system caused by the democratic developments during the 90' which happened in all the East Europe, the democratic state although it wasn't responsible for the past injustice, took over the moral and legal obligations to adjust, as soon as possible, some of the previous regime injustices, from 29 November 1994 and after. The first step was Law nr.7512 in August $1^{\text {st }} 1991$ "For sanctioning and protection of private property, for free initiative independent private activity and privatization".
\end{abstract}

Two basic elements of this process are: recognition/restitution and compensation of property. Both elements have encountered difficulties in their materialization in practice. The jurisprudence of European Court of Human Rights and the Constitutional Court of the Republic of Albania have tried to give the legal definition "restitution and compensation of property" meaning not the same as the right of property in a constitutional sense and rules of international law, but an understanding based on the principle of fairness and justice and more to the principle of the welfare state. An important role had the unification of these decisions, that taking into account the decisions of the European Court of Justice, unified judicial practice in regard to the question of restitution and compensation. Besides the repeated decisions and frequent recommendations as to improve the situation, Albanian state hasn't built yet appropriate and effective mechanisms for tackling this problem.

Keywords: Private property, restitution and compensation of property, jurisprudence, ECHR

\section{THE PROPERTY RIGHTS UNDER THE EUROPEAN CONVENTION OF HUMAN RIGHTS AND THE JURISPRUDENCE OF THE ECHR}

Article 1 Protocol 1 provides a general right of ownership. Moreover judicial practice of the European Court of Human Rights has interpreted this article in a quite extended way by giving him an autonomous meaning and without reference to domestic law states the meaning of the right of ownership. The concept of ownership is interpreted in such a way in order to include all the patrimonial rights or all property rights ${ }^{1}$. Article 1 of Protocol 1 can apply to invalid "contracts", welfare rights, and de facto indirect interference and may even include a positive obligation of the state to protect private property from others. When the court considers a complaint

${ }^{1}$ Hyskja, S - Due Process - a perspective on the elements of a judicial process, Tirana, 2000. 
of an alleged violation of the right of ownership, first it examines whether the article in question is applicable, so if there is a property right under the Convention and secondly whether this right is limited by the unjustified actions state. However, its implementation has only a limited function of unjustified actions in the practice of the Convention because it is a filter to clean those matters which do not require justification of the state. If the state fails to justify his actions, the court concludes that the property right is not infringed. This provision, however, only protects existing property and does not guarantee a right to gain ownership. So any natural or legal person has the prima face right to enjoy his property calm. This right is subject to restrictions by the public authorities. The second paragraph of Article 1 of Protocol No. 1 regulates these interventions ${ }^{2}$. Article 1 of Protocol No. 1 contains three rules, three distinct guarantees presented respectively in its three paragraphs.

The first rule, set out in the first sentence of a general nature, lays down the principle of peaceful enjoyment of property. The second rule, expressed in the second sentence provides for deprivation of property and subjects it to certain conditions. The third rule, included in the second paragraph, recognizes the right of the Contracting States to control the use of property in accordance with the general interest ${ }^{3}$.

According to the first, to determine the scope of the right of ownership, as a criterion should be considered materiality and economic benefits. It includes not only all that is material and economic benefits, but also rights acquired intangible economic benefit, for example copyrights. Article 1 of Protocol No. 1 protects existing property of a person in other words, the moment that the applicant raises claims under Article 1 of Protocol No. 1 property must exist and it must be the owner of it ${ }^{4}$.

\subsection{The contents of the property rights under the ECHR}

The right of ownership, as the right of possession, enjoyment and disposition of property, property rights is the oldest historically. Since ancient Roman law, ownership was recognized as the entirety of ius possidenti the right of possession, ius utendi fruendi the right to the fruits, ius dispodendi right of possession ${ }^{5}$. The use and quiet enjoyment of the property. Use, as an element of content ownership, is the access to possess wealth and to sum it in accordance with its economic purpose. As joy and possession are factual relationship with its property owner, so use gives the owner an exclusive right over the property. The european court of human rights and the european commission of human rights found that the prohibitions on construction with their properties limited the rights of applicants for the use of their property. However, considering the meaning of the second paragraph of article 1, the owner can legally require to perform or not to perform certain actions on his property because his rights cannot be treated as absolute ${ }^{6}$.

\subsubsection{Types of property under article 1 of protocol 1 of the convention}

The forms that can be displayed as a property are many, but the ones that enjoy the protection of Article 1 of Protocol 1 are: real estate, movable property, rights in rem, in personam rights, intellectual property, rights related as a practice, a legitimate hope and potential claims to ownership.

In Article 1 of Protocol No. 1 there is a special formulation of immovable property, as in this article talk about wealth in general and ways of protecting and limiting it, without giving any special specification for specific assets such as the items property. However, giving the meaning of real estates, each member state of the Council of Europe makes independently by civil legislation, without being conditioned by the formulation that can be given to the notion of real estates by another member state. What constitutes a common condition to be respected by all member states, is the fact that all rights under Article 1 of Protocol No. 1 in relation to property rights, are the minimal rights, which means that member states have no right to anticipate their respective legislation rights with reduced character in this field. In our country, the legal notion of real estate is found in Article 142 of the Civil Code, according to which the real estate of nature as p.sh land, sources of

\footnotetext{
2 Dollani.N, "Jus \& Justicia" No. 3, ownership under Article 1 Protocol 1 ECHR, p 98.

${ }^{3}$ Ownership is a civil legal property relationship. The personal benefits cannot be subject to the right of ownership. Regarding the fact that what may constitute the object of ownership.

4 Maho.B, "Acquisition of Real Property Ownership", pg 202

${ }^{5}$ As seen, possession, joy, moods are the basic elements and at the same time, the main characteristics of the right of ownership. The applicant in order to claim that there had been a violation of Article 1 of Protocol No. 1, he must show that has been an interference with the use of debt or other disposition of his property.

${ }^{6}$ So it's a tolerable interference in the use of the property, when intervention respects the conditions laid down by Article 1 , paragraph 2.
} 
water flows, trees of all types that are related to land, and immovable property of the destination, such as buildings that are connected to ground steadily and continuously ${ }^{7}$.

In the first sentence of Article 1 of Protocol 1, is provided the general principle that "Every natural or legal person is entitled to the peaceful enjoyment of property". From here it turns out that a physical or juridical person may be complaining about interference with his property. The meanings of these terms, a natural person, legal entity, explained by civil law. In the practice of the European Court of Human Rights, these applicants are considered direct victims. But Article 1 can be applied to the so-called transversal victims. Indirect victim is the person who can prove that between him and the direct victim has a special personal connection and the breach has cost to him a harm or he has a justifiable personal interest for the infringement to end. In judicial practice, the indirect victim's problem has come up with applications of shareholders of companies. Thus, the European Commission of Human Rights has introduced criteria "of considerable proportions" in the early issues, where the applicant was the owner of a land where he had established a company and had its own president. Violation of ownership may come as a result of a court decision or legislation. Interference with property can be due to the action and any international law or constitutional instrument, when they affect the right of property. But Article 1 may be based on the public body when it is not directly responsible for the intervention to the property 8 .

\subsubsection{Implementation of the general principles of international law. Rights and economic freedom:}

Through these rights is expressed the economic and social status of man and citizen. In their guarantee has more desire, inspiration and purpose, while less fruition due to material weakness, but state volunteering costs. Those rights belong to the new generation promoted on XIX century, as a result of economic and social function of the state. The main promoters: the Weimar Constitution of 1919, the Universal Declaration of Human Rights of 1948 and the International Covenant on Economic, Social and Cultural Rights since 1966. But among them are also some very old rights. Rights and economic freedoms can discover the economy character in the country and as an important right among them, is the right to property. Despite shortages and general expressions, one thing is clear that the UN Charter of Human Rights has an internationalization way. In this way Member States to accede to the UN charter which is a multilateral treaty, indirectly recognize that human rights are already a problem of international concern and not just a sphere of their domestic jurisdiction? Universal Declaration announces two categories of rights: On one hand civil and political rights and on the other hand, as a necessary complement, the economic, social and cultural rights. The two categories constitute a unity, which is the basis for realization of rights and freedoms in practice. It is worth mentioning that the Declaration states that the rights it proclaims, is not absolute. It is provided for the cases when the state may restrict the exercise of these rights, but these restrictions are intended to "ensure respect for the rights of others" and when they are necessary "to ensure public order and the general welfare in a democratic society". But even this reserve is not absolute and Article 30 of the Declaration makes clear that "nothing in this Declaration may be interpreted as giving the right to a state or a group of persons to perform actions and take steps that lead to denial of rights and freedoms expressed in the Declaration". In general the "expropriation" under international law means taking property from the state of a private individual. It can be a separate asset, as in the case of a plantation, or a chain industry. "Nationalization" is regarded as the best example of expropriation of the second kind. However expropriation is not limited simply by taking ownership. It may also include any activity that violates state property rights of foreign nationals, such as the imposition of punitive taxes, the obligation to respect local property or permanent ban of the sale ${ }^{10}$. In 1962 the UN General Assembly adopted a resolution on permanent sovereignty over natural resources. It stipulated, inter alia, that expropriation should be based on reasons of public safety needs, or national interests, which are recognized as priority to those that are essentially individual or private interests, whether domestic or foreign ${ }^{11}$. According to this resolution an expropriation is lawful, if it is undertaken for reasons of public order, security or national interest and pay compensation only if "appropriate". The important thing is to know that the assessment whether the compensation paid "appropriate" is made on the basis of the expropriating state legislation and

\footnotetext{
${ }^{7}$ Maho.B, "Acquisition of immovable property ownership", p 206.

8 In this article, interference is provoked by a third individual private party. However intervention may not result exclusively from a private individual. This is because a public body should be included directly.

${ }_{9}$ Puto.A, "Public International Law", p 212.

10 Dixon.M, "International Law", p 350.

11 In such cases to the owner belongs the appropriate compensation in accordance with applicable state rates take these measures within the exercise of its sovereignty and in accordance with international law. This resolution is closely linked to the principle of self-determination and must take into account that it characterizes as a fair expropriation born with sovereignty. This means that expropriation is prima facie lawful, provided that the conditions set by international law.
} 
international law. For more than these requirements, judicial case law also suggests that lawful expropriation should not be discriminatory, is deliberately directed against the citizens of a single state ${ }^{12}$.

This element was reinforced and strengthened through the 1986 resolution in the General Assembly of the UN on the right to the economic development of key states. The provisions of this statement read as follows: Article 11. The right to development is an inalienable human right by which any person of all populations is entitled to participate in, contribute to, and enjoy development economic, social, cultural and political, that all human rights and fundamental freedoms can be fully realized. The human right to development also implies the full realization of the right of peoples to self-determination, which includes, in accordance with the relevant provisions of both International Covenants on Human Rights, in the exercise of their inalienable right to sovereignty complete coverage of all their natural wealth and resources. Article 21 . The human person is the central subject of development and should be an active participant and beneficiary of the right to development. All human beings have a responsibility for development, individually and collectively, taking into account the need for full respect for their human rights and fundamental freedoms as well as their duties to the community, which alone can ensure the fulfillment of the free and the full human being, and they should therefore promote and protect in a suitable political, social and economic development. States have the right and duty to formulate appropriate national policies aimed at developing continuous improvement of the welfare of the entire population and of all individuals, on the basis of their active, free and meaningful participation in development and fair distribution of benefits derived from it ${ }^{13}$.

The right to property is a very important fundamental right in a democratic state. As such it is found enshrined in Article 1 of Protocol 1 of the European Convention on Human Rights. It is a fact that the Albanian reality appears rather problematic in view of the standards required in Article 1 of Protocol 1. From the European Court of Human Rights are some decisions through which have found a violation of the right to property. It were given two pilot decisions (Ramadhi and Driza) and a press statement which clearly expressed the Strasbourg concerning infringement of the right of property in Albania and therefore have asked for a solution in legal and financial problems of our country regarding this.

Article 1 of Protocol 1 is the only article of the Convention which provides the regulation an economic right. Article 1 of Protocol 1 is the only article of the Convention that expressly provides: "Every natural or legal person is entitled to the peaceful enjoyment of his property. No one may be deprived of his possessions except in the public interest legal and subject to the conditions provided for by law and by the general principles of international law. However, the above provisions shall affect the right of states to enact such laws as it deems necessary to control the use of property in accordance with the general interest or to secure the payment of taxes or other contributions or penalties ". ECHR jurisprudence has defined three main rules or warranty given respectively in three sentences of this article. They are: a) peaceful enjoyment of property, b) the possibility of deprivation of property, but under certain conditions, c) the possibility of intervention and control the use of property in accordance with the general interest ${ }^{14}$. These rules are set for the first time in Longroth SPORRONG decision against Sweden "Heirs of Mr. SPORRONG sought as material damage 13,284,500 SEK and Ms. Lönnroth 10912303, each of these amounts consisted of a waste of money December 31, 1980. The applicants complained about the moral damage but they left the Court to decide compensation. To show the existence of damage, the Court begun to define the period when the damage occurred. It was admitted that the municipality needed a time to four years to make the necessary studies for the preparation of the final decision regarding the planned expropriation. The court determined the heirs to 19 years for Mr. SPORRONG and four for Ms. Lönnroth. It then determined the components of damage. If the applicant did not suffer impoverishment during this period (storage commercial value of the building and lack loss of income); however they have suffered damage during this period: barrier to freely use the property; barrier to mortgage debt; buildings depreciation; Unable to do a renovation project; above all uncertainty over. So the moral damage is caused by the violation of Article 1.6. Regarding the assessment of the damage appears more complex issue, due to the difficulty that makes the calculation of the loss of future opportunities".

\footnotetext{
12 Dixon.M, "International Law", p 351.

${ }^{13}$ Although the right to development is a right hard to determine in concrete terms and in less legal matters, the articulation of this right in 1986 that has enabled the international community to support it and develop: Principles other international trade and the development of special treatment and privileged to developing countries need to address the problem of international debt. It can also be said that the right to development was a contributor to the adoption of the Millennium Development Goals by the international community in 2000, at the dawn of the new millennium.

${ }^{14}$ Zagonjori. J., Jus \& Justicia No. 3, The Impact of the ECHR in Albania, p 30
} 
Another decision that is worth mentioning and that contains a special importance and is recommended for Albania and other East countries, is the Jasiuniene decision against Lithuania at 6 March 2003 ${ }^{15}$. The European Court of Human Rights reiterated that the right to a court embodied in Article 6 of the Convention would be quite illusory and voiding in a final court decision and binding character left unimplemented in damage to any of the parties. Having failed in the execution of this ruling, the Lithuanian authorities had actually deprived Article 6/1 of the Convention any beneficial effect. For this reason there has been a violation of this article. On the other hand it was not necessary to consider its claims in view of Article 13 unless the requirements of the provision of this absorbed from the provision of Article 6/1 ${ }^{16}$. In connection with the complaint of researchers that she had not been able to recapture such a site after recreating the Lithuanian State, the Court noted that the Convention itself does not guarantee the right to return the property. The hope that a property which has been forgotten for years, can be reversed, cannot be seen as an "asset" for the purposes of Article 1 of Protocol 1 of the Convention. It was clear that the applicant had no hope of return, based on the law of the land under the applicable settlement Lithuanian normative and authorities required to tune the compensation in benefits in kind or in cash. Article 1 of Protocol No. 1 was therefore not applicable in relation to this complaint. While Article 14 cannot be considered alone, then neither he could find application here. So there has been a violation of Article 1 of Protocol 1 taking separately or together with Article $14^{17}$.

This important decision summarizes in a quite short way, enough of controversial issues that arise in connection with the return of private property in Albania, as in other countries of Central and Eastern Europe and the former Soviet Union. It should be noted that under the Convention, there is a right to regain a title that was suppressed for so many years under the communist regime. Also note that there can be no right to compensation for a property that was confiscated or nationalized during the old regime. In cases where countries have risen a system for the return of property that is either broken or confiscated and when this right is confirmed regularly by a competent national authority, the right of "confirmed" for property restitution or compensation constitutes "assets" for purposes of Article 1 of Protocol 1 and consequently the latter applies.

The failure of the state authorities of a court decision which ordered restitution if either compensation, if the return is not possible. In addition to Article 1 of Protocol 1 would lead to the violation of Article $6 / 1$ of the Convention. The right to a fair trial as provided for and guaranteed by Article 6/1 includes the right to a prompt execution of a judicial decision.

Unjustified delays in the payment of compensation may violate Article 6 in the same way as delays in decision making about any dispute over the ownership right or the amount of compensation to be awarded.

\section{Papamichalopoulos decision against Greece 24 June 1993}

This issue is too important mainly for three reasons. The first has to do with the timely implementation of the convention or in relation to highly unusual period of its implementation, as was that of Greece in the years 1967-1974, or about continuing violations. Despite that, as the Court itself acknowledged, Greece did not accept the right of individual application at the time of expropriation, sequential character of this act made him to submit to the jurisdiction of the Commission and the Court to assess whether it was in accordance with a material provision of the Convention in this case Article 1 of Protocol No. 1. such an approach is more interesting for the individual situation Çam origin, or generally Albanian citizens who claim a violation of the right of ownership over properties that each of them had in Greece.

Given that in a case such rich opportunities for acceptance of jurisdiction by the Court will be much more difficult for a variety of reasons, a combination of this jurisprudence with respect to Brumărescu Vasilescu matter and could lead to solutions preferably in connection with the claims of these individuals.

Second issue is important that it leads to punishment as incompatible with the Convention to a position that regardless of how alleged by the Greek state, constituted de facto expropriation. For this purpose the Strasbourg Court not only referred to the moment of expropriation in itself, but it also received the state's

\footnotetext{
15 This issue had to do with the return of private property in Lithuania in situations similar to those encountered in Albania and in other former communist. The applicant claimed that the nationalization and destruction of the ownership of the mother of Soviet power and the inability of the Lithuanian authorities to restore or compensate the land violated Article 1 of Protocol 1, if only to get to Article 14. She also complained that the non-execution the decision of the District Court on 3 April violate Articles 6 and 13 of the Convention.

${ }^{16}$ In conjunction with Article 1 of Protocol 1, the Court noted that it had no jurisdiction to consider the applicant's complaint about the nationalization of land owned by the mother and the destruction of her home, because they relate to events that had occurred prior to the entry into force of the Convention and Protocol 1 in relation to Lithuania.

${ }^{17}$ Interpretation of the European Convention on Human Rights. Tirana. 2012
} 
inability to real compensation, including delays and inefficiency of the Greek judicial and administrative authorities in this regard.

Third issue is also important for the problem of restitutio ad integrum. For the purposes of issuing its decision in relation to remuneration, the Court not only entered the detailed analysis of the procedure for calculating the damage, but accepted full payment of value added land by giving them the cost of buildings raised on them and by calculating a percentage of potential delays in connection with the payment of respective amounts. No less important from the point of view of the jurisprudence of the Court's acceptance of a moral prejudice to the applicants in such a case to the inability of the authorities to allow them the enjoyment of property ${ }^{18}$.

In the recent case of Albania is the VRIONI case and others against Albania demanding their right to property Court and this Court unanimously decided: "that there has been a violation of Article 1 of Protocol No. 1 and that the respondent State had to pay the applicants, within three months from the date on which the judgment became final in accordance with Article 44/2 of the Convention, the following amounts, to be converted into the national currency of the respondent State in rate applicable on the date of settlement".

Besides making repeated and frequent recommendations for improvements, the Albanian state has not built adequate and effective mechanisms for resolving this. The existence of a legal vacuum in the domestic system, the lack of effective tools for solving the issue eventually returning and compensation of property, constitute very disturbing factors that require urgent intervention of the Albanian state. Finally we can say that is asked repeatedly and directly from international institutions, to take urgent measures and priorities for restitution and compensation of property in the implementation of final decisions undertaken by the Albanian authorities.

\section{CONCLUSIONS}

Till Albania has reached democracy, propriety has been the major juridical, economic and social problem. During the communist period, everything was centralized so the Albanians had no cultural experience about private propriety. The first laws, as described in the article, created more confusion than solved this problems. Now Albania is a member of the European Council, and as a consequence the Court of Strasbourg has condemned the Albanian Government for the numerous problems caused to individuals in this field. This sentences have had and still causes a big economic loss to the Albania State that is impossible to pay. Certainly the democratic experience has brought to better laws, but solutions and the bill the State has to pay to individuals is calculate to last for other $15 / 20$ years in order to bring a general social justice.

\section{REFERENCE LIST}

Bianku. L., (2007), Jurisprudenca e Gjykatës së Strasburgut, Tirana (Albania), "EDLORA" Publishing.

Daci J., (2008), Human Rights, Tirana (Albania), Daci law firm.

Duka, V. (2007). Histori e Shqipërisë, 1912-2000. Tiranë: Shtëpia Botuese Kristalina-KH.

Galgano. F., (2006), E Drejta Private, Tirana (Albania), Botime Luarasi.

Kondili. V. (2008), E Drejta Civile, Dispenca II, Tirana (Albania).

Maho. B., (2009), Fitimi i Pronësisë mbi Pasuritë e Paluajtshme, Tirana (Albania), UET Press.

Maho. B., (2010), Zhvillimet e fundit mbi Pronësine, Tirana (Albania).

Nowicki. M., (2003), Rreth Konventës Europiane, Komentar i shkurtër mbi KEDNJ, Tirana (Albania), Botimet Morava.

Nuni. A. \& Hasneziri. L, (2008), E Drejta e Pronësisë, Tirana (Albania).

\footnotetext{
18 Impact of the ECHR decisions on the right of property in Albania. Respect for and protection of property rights has been the focus of a considerable number of complaints lodged with the ECHR for our country. Failure to respect the right of ownership as one of the most fundamental rights in a democratic state is a bit worrying situation for the Albanian reality. The concern in this regard is twofold because: a) it violated the rights of individuals and b) the Government is forced to because of the decision to pay substantial sums.
} 


\section{LAW REFERENCES}

General of the codification of legislation to RPSSH, volume II, a publication of the Prime Minister, Tirana 1958.

The Constitution of the Republic of Albania with the interpretations of the Constitutional Court, Alb Juris Publishing, Tirana 2008

Albanian Constitution and the US Constitution, Publishing Grand Parent ', Tirana 2006.

RPSSH codes, Publishing Legal Bureau at the Council Ministers, Tirana, 1982.

Constitutional Provisions-adopted in 1992.

European Convention of Human Rights, Article 1 of Protocol 1 to the right of property.

Decisions of the United Chambers of the Supreme Court.

Decisions of the Constitutional Court of Albania.

Summary Legislation on Restitution and Compensation of Property, Publishing of SPC, Tirana, May 2009

Summary of decisions of the European Court of Human Rights against Albania, SPC Edition, June 2010

Civil Code of the Republic of Albania, approved by Law nr.75850, dated 29.7.1994, SPC Publishing, Tirana.

Civil Procedure Code of the Republic of Albania approved the law nr.8116, dated 29.3.1996, SPC Publishing, Tirana

Law No. 7491, dated 29.4.1991, "On Page's constitutional provisions"

Appendix to the Law No. 7491, dated 29.4.1991, "On Page's constitutional provisions", Nr.7692, dated 3.31.1993

Law no, 7698 dated 15.04.1993 "On the recognition, restitution and property compensation"

Law no, 9235 dated 29.07.2004 "On the recognition, restitution and compensation of property"

Law No. 9235, dated 29.7.2004 On Restitution and Compensation of Property ", amended by Law No. 10 207, dated 23.12.2009.

Law no. 9583, dated. 17.07.2006 "On Amendments to the Law No. 9235, dated 29.07.2004" On restitution and compensation of property ". 